\title{
The role of PR-Set7 in replication licensing depends on Suv4-20h
}

\author{
David B. Beck, ${ }^{1}$ Adam Burton, ${ }^{2}$ Hisanobu Oda, ${ }^{1}$ Céline Ziegler-Birling, ${ }^{2}$ Maria-Elena Torres-Padilla, ${ }^{2,3}$ \\ and Danny Reinberg ${ }^{1,3}$

\begin{abstract}
${ }^{1}$ Howard Hughes Medical Institute, Department of Biochemistry, New York University School of Medicine, New York, New York 10016, USA; ${ }^{2}$ Institut de Génétique et de Biologie Moléculaire et Cellulaire, CNRS/INSERM U964, CU de Strasbourg, F-67404 Illkirch, France
\end{abstract}

PR-Set7 is the sole monomethyltransferase responsible for H4K20 monomethylation (H4K20me1) that is the substrate for further methylation by Suv4-20h1/h2. PR-Set7 is required for proper cell cycle progression and is subject to degradation by the CRL4 ${ }^{\text {Cdt2 }}$ ubiquitin ligase complex as a function of the cell cycle and DNA damage. This report demonstrates that PR-Set7 is an important downstream effector of CRL4 ${ }^{\text {Cdt2 }}$ function during origin of DNA replication licensing, dependent on Suv4-20h1/2 activity. Aberrant rereplication correlates with decreased levels of H4K20me1 and increased levels of H4K20 trimethylation (H4K20me3). Expression of a degradationresistant PR-Set7 mutant in the mouse embryo that is normally devoid of Suv4-20 does not compromise development or cell cycle progression unless Suv4-20h is coexpressed. PR-Set7 targeting to an artificial locus results in recruitment of the origin recognition complex (ORC) in a manner dependent on Suv4-20h and H4K20me3. Consistent with this, H4K20 methylation status plays a direct role in recruiting ORC through the binding properties of ORC1 and ORCA/LRWD1. Thus, coordinating the status of H4K20 methylation is pivotal for the proper selection of DNA replication origins in higher eukaryotes.

[Keywords: H4K20; ORC; PR-Set7; Suv4-20; cell cycle; chromatin]

Supplemental material is available for this article.

Received May 3, 2012; revised version accepted October 15, 2012.

The proper maintenance and control of genome integrity is an important and well-coordinated process. Many factors function to coordinate the proper progression of the cell cycle, including those that directly regulate the chromatin states critical for replication, mitotic condensation, and cell division. Central among these chromatinassociated cell cycle regulators is PR-Set7/Set8/Setd8, the sole mammalian histone H4K20 monomethyltransferase. In embryonic stem (ES) and differentiated cells, PR-Set7 deletion results in massive DNA damage and defects in cell cycle progression (Beck et al. 2012), leading to an accumulation of cells in $\mathrm{G} 2 / \mathrm{M}$ phase (Jorgensen et al. 2007; Tardat et al. 2007; Houston et al. 2008; Oda et al. 2009). Moreover, PR-Set7 is degraded prior to $S$ phase and after UV damage by a PCNA/CRL4 ${ }^{\text {Cdt2 }}$-dependent mechanism, a conserved means to regulate origins of DNA replication licensing (Abbas et al. 2010; Centore et al. 2010; Oda et al. 2010; Tardat et al. 2010). Thus, the oscillation of PR-Set7 levels during the cell cycle suggests a means by

${ }^{3}$ Corresponding authors

E-mail danny.reinberg@nyumc.org

E-mail metp@igbmc.fr

Article published online ahead of print. Article and publication date are online at http://www.genesdev.org/cgi/doi/10.1101/gad.195636.112 which H4K20 methylation (H4K20me) regulates cell cycle progression. To date, there are only two known substrates for PR-Set7-H4K20 and p53K382-with most functions attributed to PR-Set7 resting on its catalysis of H4K20 monomethylation (H4K20me1) (Beck et al. 2012).

H4K20me is unique among histone modifications in that it oscillates during the cell cycle. The levels of H4K20me are directly controlled by three sets of enzymes. PR-Set7 catalyzes H4K20me1, which is required for subsequent catalysis of $\mathrm{H} 4 \mathrm{~K} 20 \mathrm{di} /$ trimethylation (H4K20me2/3) (Nishioka et al. 2002; Rice et al. 2002) via the activity of Suv4-20h1/h2 (Schotta et al. 2008), or is subject to demethylation, along with $\mathrm{H} 3 \mathrm{~K} 9 \mathrm{me1}$, by PHF8 activity (Liu et al. 2010; Qi et al. 2010 ). Misregulation of PR-Set7 or Suv4-20h1/h2 (Suv4-20h) causes increased sensitivity to DNA damage and defects in the cell cycle (Schotta et al. 2008; Oda et al. 2009).

How PR-Set7 and H4K20me1 function to regulate the cell cycle remains an open question. PR-Set7 is normally absent during DNA replication and peaks during mitosis. In addition, the deletion or knockdown of PR-Set7 gives rise to marked defects in both mitosis and $S$ phase. More recently, gain-of-function experiments have suggested a role for PR-Set7 in proper DNA replication (Abbas et al. 2010; Tardat et al. 2010). Expression of a nondegradable PR-Set7 
mutant, PR-Set7 ${ }^{\text {PIPM2 }}$ (PCNA-interacting peptide [PIP] degron mutant), is highly toxic, and this toxicity is dependent on PR-Set7 catalytic activity (Abbas et al. 2010; Centore et al. 2010). While this phenomenon may be due to a multitude of reported defects, a leading culprit is the uncontrolled rereplication of the genome upon expression of PR-Set $7^{\text {PIPM2}}$. Consistent with this, loss of PR-Set7 enzymatic activity causes defects in origin of replication firing (Jorgensen et al. 2007; Tardat et al. 2007).

The mechanisms behind origin of replication firing in higher eukaryotes are poorly understood. In contrast to the case of lower eukaryotes, there is no evidence of a sequence-specific directed mechanism for origin recognition and firing (Gilbert 2010). For this reason, other features of chromatin are candidates as the targets for recruitment of the DNA replication machinery, although, as yet, no specific histone post-translational modification has correlated with origins of replication (Karnani et al. 2010; Eaton et al. 2011; Mesner et al. 2011). Because origin of replication firing does correlate with PR-Set7 activity, PR-Set7 and/or H4K20me1 may potentially provide a chromatin-dependent mechanism for recruitment of the origin recognition complex (ORC).

In this study, we sought to determine how PR-Set7 functions in the origin of replication licensing pathway. We found that the rereplication phenotype caused by loss of the CRL4 ${ }^{\text {Cdt2 }}$ ubiquitin ligase complex is fully rescued upon codepletion of PR-Set7. Either Cdt2 knockdown or PR-Set7 stabilization results in increased global levels of $\mathrm{H} 4 \mathrm{~K} 20 \mathrm{me} 3$, suggesting that H4K20me3 is a key effector in the rereplication pathway. In line with this, we show that the defects in cell cycle progression and massive DNA damage that result when cells are exposed to a degradation-resistant version of PR-Set7 are a consequence of Suv4-20h activity. Forced targeting of PR-Set7 using a GAL4-UAS system results in elevated H4K20me3 at this locus and increased ORC recruitment, while depletion of Suv4-20h1 led to a drastic reduction in ORC recruitment. This recruitment involves two different components of ORC-ORC1 and ORCA (LRWD1)that bind directly to $\mathrm{H} 4 \mathrm{~K} 20 \mathrm{me} 2 / 3$ in vitro. Our results suggest that PR-Set7 modulates the chromatin environment such that the chromatin is permissive for replication firing through the downstream action of Suv4-20.

\section{Results}

PR-Set7 is a major downstream effector of Cdt2 function

During our initial characterization of PR-Set $7^{\text {PIPM2}}$, we noticed that expression of this mutant elicited toxic effects in a variety of cell lines (Supplemental Fig. 1A). PRSet $7^{\text {PIPM2 }}$ contains mutations in the second PIP domain, PIP degron, that inhibit PR-Set7 binding to PCNA and thus blocks the normal process of PCNA-dependent CRL4 ${ }^{\text {Cdt2 }}$ mediated degradation of PR-Set7 after UV damage and during S phase (Abbas et al. 2010; Centore et al. 2010; Oda et al. 2010; Tardat et al. 2010). PR-Set7 also contains another PIP domain (PIP1) that is not required for PCNA binding or CRL4 ${ }^{\mathrm{Cdt} 2}$-mediated degradation (Supplemental Fig. 1A). We first readdressed whether expression of PRSet $7^{\text {PIPM2 }}$ has an effect on cell cycle progression. We expressed a retrovirus encoding PR-Set $7{ }^{\mathrm{PIPM} 2}$ in HeLa and U2OS cells that led to sustained PR-Set7 levels, as expected (Supplemental Fig. 1B; data not shown). HeLa cells expressing PR-Set $7^{\text {PIPM2 }}$ displayed an altered cell cycle profile with increased population of cells within G2/M phase along with an increased number of cells containing +4 n DNA content and increased nuclear volume that are replicating DNA $\left(\mathrm{EdU}^{+}\right)$(Fig. 1A; Supplemental Fig. 1C), suggesting rereplication or aberrant origin of replication firing in agreement with previous observations (Abbas et al. 2010; Tardat et al. 2010). Thus, stabilization of PR-Set7 during S phase leads to increased rereplication and G2/M arrest, a unique characteristic of proteins that regulate origin of replication licensing (Arias and Walter 2007; Abbas and Dutta 2011; Havens and Walter 2011), and suggests that the abnormal persistence of PR-Set 7 throughout the cell cycle leads to cell cycle alterations.

To address this hypothesis directly, we next sought to determine whether the cell cycle defects seen in cells lacking Cdt2 were due to excess PR-Set7 using RNAimediated knockdown of Cdt2, PR-Set7 itself, and another Cdt2 degradation target, Cdt1. Cdt2 has been previously shown to participate in cell cycle-regulated degradation of PR-Set7, and we found that upon Cdt2 knockdown, PR-Set7 was stabilized (Fig. 1B; Oda et al. 2010). Importantly, loss of $\mathrm{Cdt} 2$ also gave rise to robust defects in cell cycle progression, including G2/M arrest and rereplication (Fig. 1C; Supplemental Figs. 2, 3A). Because this phenotype might potentially be due to other Cdt2 targets, we tested whether the stabilization of Cdt1 might contribute to this effect by performing double-knockdown experiments. Depletion of PR-Set7 or Cdt1 rescued the cell cycle arrest observed in cells lacking Cdt2, suggesting that Cdt 2 regulates cell cycle progression through control of both PR-Set7 and Cdt1 levels (Fig. 1C; Supplemental Figs. 2, 3A). On the other hand, PR-Set7 siRNA treatment was unable to rescue the cell cycle arrest observed upon knockdown of another, more promiscuous member of the CRL4 ${ }^{\text {Cdt2 }}$ complex, DDB1 (Supplemental Fig. 4A,B). These findings indicate that PR-Set7 is a specific, critical downstream effector of CRL4 ${ }^{\mathrm{Cdt} 2}$-regulated origin of replication licensing.

CRL4 ${ }^{\mathrm{Cdt} 2}$ has a well-characterized role in regulating the dynamics of origins of DNA replication. To determine the mechanism by which PR-Set 7 and Cdt 2 may regulate origin of replication licensing, we examined the effects of loss of Cdt2 and PR-Set7 on H4K20 methylation. Loss of Cdt2 alone resulted in PR-Set7 stabilization along with a decrease in H4K20me1 levels and a concomitant increase in H4K20me3 (Fig. 1B). The elevated levels of PRSet7 likely led to increased levels of H4K20me1 that was efficiently converted to H4K20me3 (Abbas et al. 2010). In keeping with this, the increase in H4K20me3 levels was reversed upon codepletion of PR-Set7, suggesting that a potential cause of rereplication is the overabundance of H4K20me3. In contrast, codepletion of Cdt1 did not restore H4K20me3 levels (Fig. 1B). Although the observed alterations in H4K20me3 levels likely reflect changes in PR-Set7 
Beck et al.
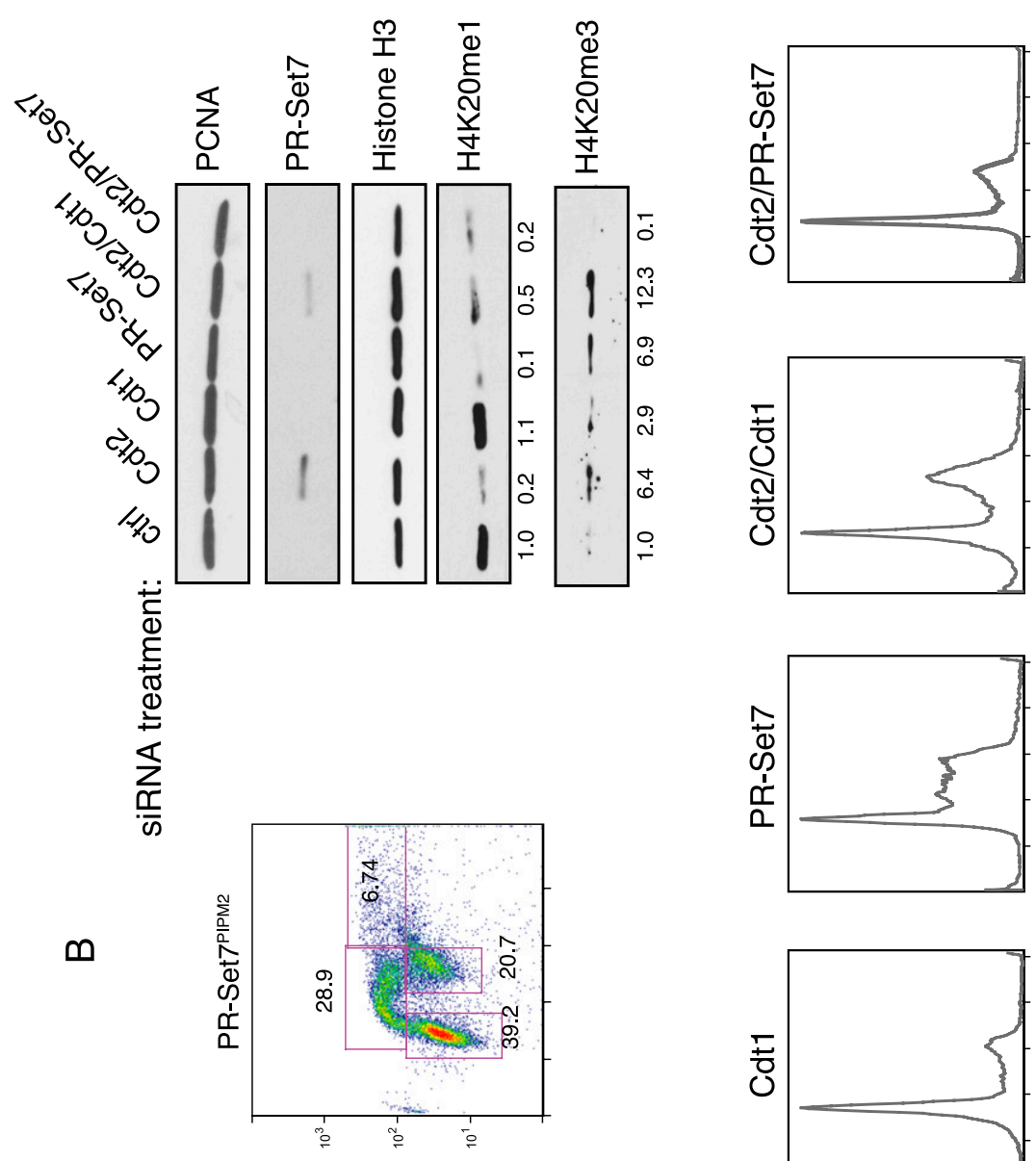

告
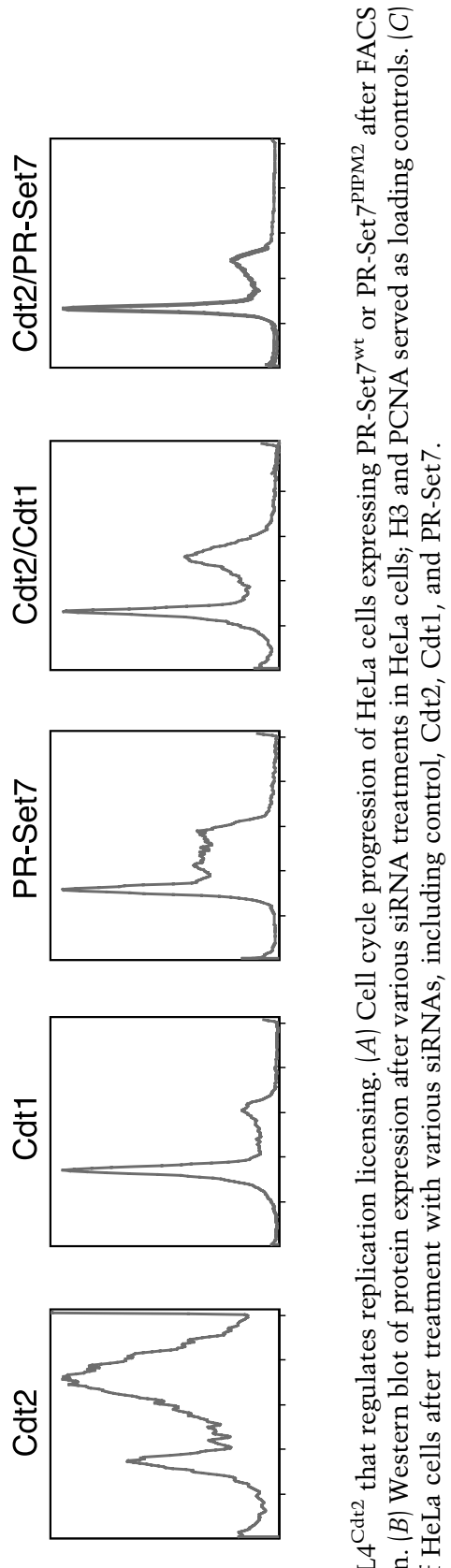

A

:

品品

希离

ชั

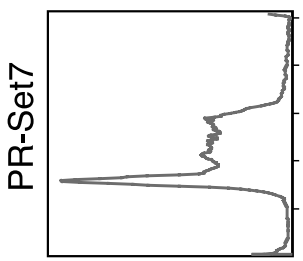

亖告

泀苞

更

党

ठิ
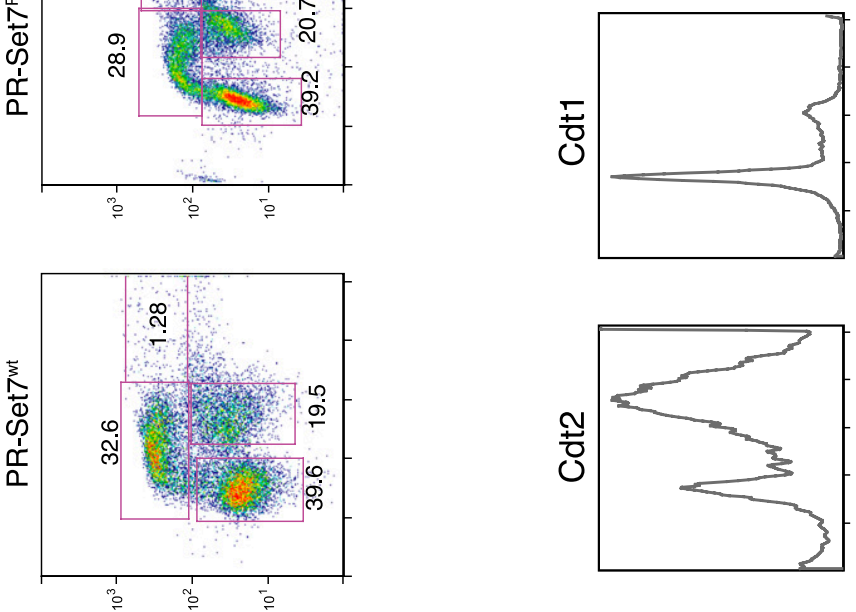

至

萦荅离

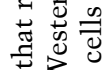

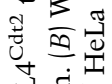

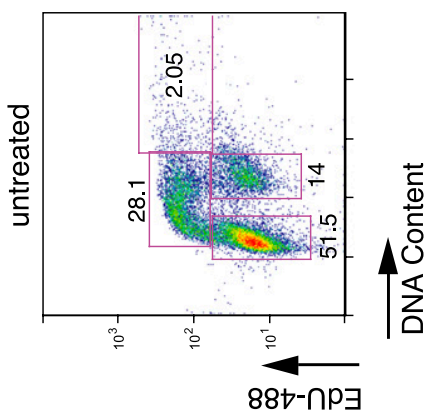

$<$

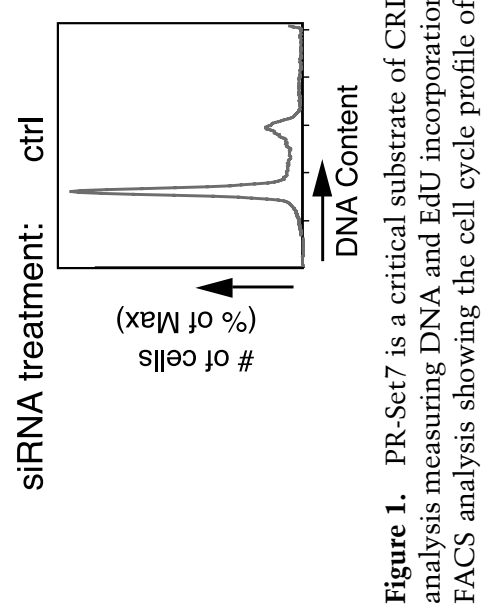


levels, we cannot exclude the possibility that changes in the cell cycle may contribute. Our findings are partially consistent with a recent report indicating that H4K20me3 levels are elevated during G1/S phase (Zee et al. 2012).

Suv4-20h1/h2 are required for PR-Set $7^{\text {PIPM2 }}$-mediated cell cycle defects in differentiated cells

Despite the defined role of H4K20me1 in mitotic condensation, it is not clear how this modification is biologically relevant during DNA replication, since both
PR-Set7 and H4K20me1 are mostly absent during S phase. As a first step toward understanding this enigma, we sought to determine whether the function of PR-Set7 during DNA replication was dependent on the downstream di- and trimethylation states of H4K20me catalyzed by Suv4-20h1/h2 (Schotta et al. 2008), given that H4K20me2/3 are at their highest levels during G1 and S phases (Abbas et al. 2010). To test this possibility, we

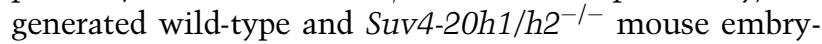
onic fibroblasts (MEFs) (Suv4-20 dn) in which the PRSet $7^{\text {PIPM2 }}$ is expressed under the control of an inducible
A

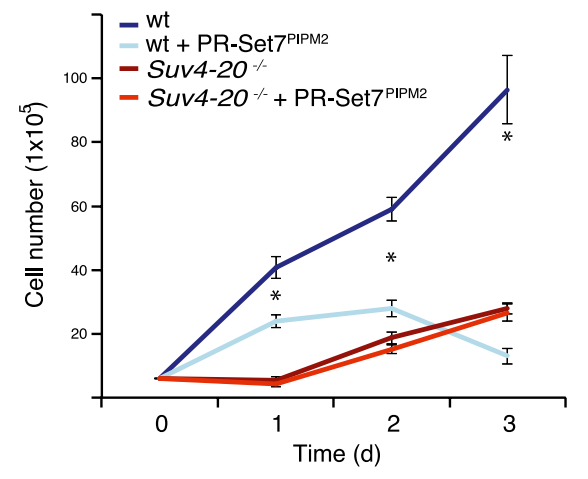

C

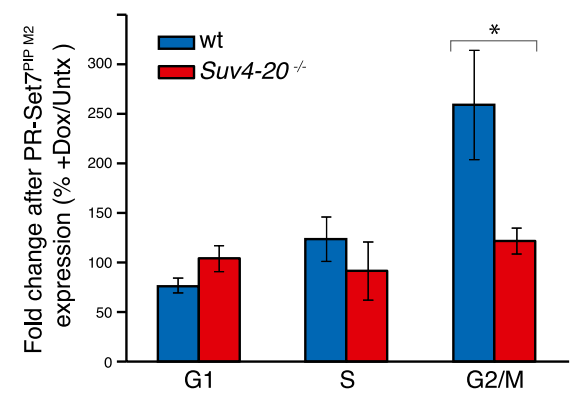

$\mathrm{E}$

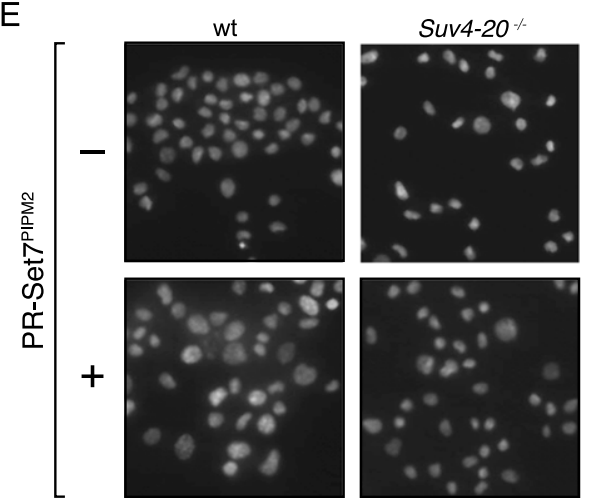

B

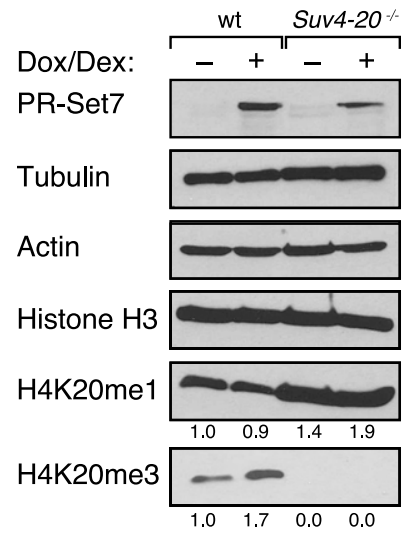

D
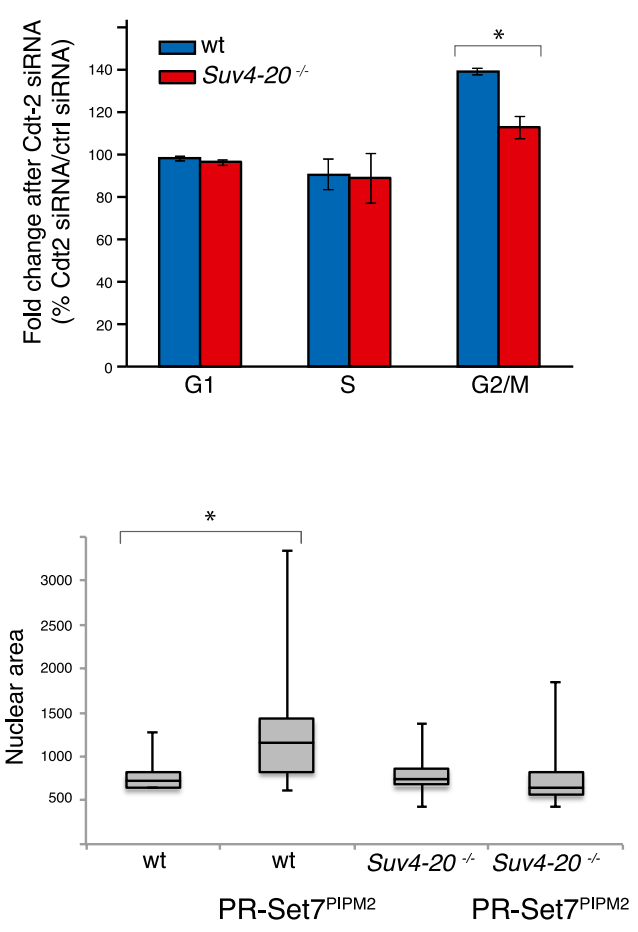

Figure 2. PR-Set $7^{\mathrm{PIPM} 2}$ toxicity is dependent on Suv4-20 and H4K20me2/3 in MEFs. (A) Proliferation of wild-type (wt) and Suv4-20 ${ }^{-/-}$ MEFs after inducible expression of Flag-HA PR-Set $7^{\text {PIPM2}}$. Induction of PR-Set $7^{\text {PIPM2 }}$ after addition of doxycycline and dexamethasone at day $0 .(B)$ Western blot of wild-type and Suv4-20-/- MEF lysates after inducible expression of PR-Set $7^{\text {PIPM2 }}$. (C) FACS analysis of cell cycle distribution of wild-type and Suv4-20-/- MEFs before and after induction of PR-Set $7^{\text {PIPM2 }}$. (D) FACS analysis of cell cycle distribution of wild-type and Suv4-20 $0^{-/-}$MEFs before and after treatment with siRNA against Cdt2. (E) DAPI staining and quantification of the nuclear size of wild-type and Suv4-20 $0^{-1-}$ MEFs after induction of PR-Set $7^{\text {PIPM2 }} . n=3$ for proliferation and cell cycle experiments. $\left(^{\star}\right)$ Statistical significance with $P<.05$. 
doxycycline/dexamethasone-responsive promoter (Fig. 2B). Expression of PR-Set $7^{\text {PIPM2 }}$ in wild-type MEFs caused a striking reduction in growth rate (Fig. 2A) but was ineffectual in the case of Suv4-20 dn MEFs (Fig. 2A). Expression of the PR-Set $7^{\text {PIPM2 }}$ led to both a slight decrease in H4K20me1 levels and an increase in H4K20me3 levels in wild-type MEFs, neither of which was observed in the case of Suv4-20 dn MEFs (Fig. 2B). These results implicate a globally increased transition from the mono- to the trimethylated state of H4K20 in the pathway leading to cell cycle defects mediated by PR-Set $7^{\text {PIPM2 }}$.

We next compared the cell cycle profile of wild-type and Suv4-20 dn MEFs as a function of PR-Set $7^{\text {PIPM2 }}$ expression. In contrast to wild-type MEFs in which PR-Set $7^{\text {PIPM2 }}$ expression led to a 2.5-fold increase in G2/M-phase cells, similar to our observation in HeLa cells and earlier work by other groups (Centore et al. 2010; Tardat et al. 2010), Suv4-20 dn MEFs did not display changes in the cell cycle profile upon expression of PR-Set $7^{\text {PIPM2 }}$ (Fig. 2C). Similarly, Cdt2 siRNA treatment of wild-type but not Suv4-20 $d n$ MEFs caused an accumulation of cells in G2/M phase (Fig. 2D; Supplemental Fig. 3B). Importantly, untreated wild-type and Suv4-20 dn MEFs have similar amounts of cells in G2/M phase (Supplemental Fig. 5). Finally, while wild-type MEFs showed increased nuclear volume upon induction of PR-Set $7{ }^{\text {PIPM2 }}$ expression, this was not the case for Suv4-20 dn MEFs (Fig. 2E). These combined results demonstrate that the cell cycle progression defects caused by PR-Set7 stabilization during $S$ phase are dependent on Suv4-20h and its products, H4K20me2/3.

Absence of H4K20me3 prevents toxicity of PR-Set7 ${ }^{\text {PIPmt }}$ and DNA damage in PR-Set $7^{-1-}$ early embryos

We previously showed that deletion of PR-Set7 in mice results in embryonic death at the transition between the four- and eight-cell stage (Oda et al. 2009). This lethality can be rescued upon reintroduction of a catalytically active PR-Set7 into PR-Set7 ${ }^{-/-}$embryos. In contrast to other cell types in which PR-Set7 is depleted, there is no accumulation of DNA damage in the PR-Set $7^{-1-}$ embryo (Oda et al. 2009). To better understand the aberrant functioning of PR-Set $7^{\text {PIP }}$ mutants in vivo, we first investigated whether PR-Set $7^{\text {PIPM1M2 }}$ expression could rescue the PR-Set $7^{-1-}$ embryos. We collected two-cell stage embryos from $P R-S e t 7^{-1+}$ crosses and injected one of the two cells with mRNA encoding PR-Set $7^{\text {PIPM1M2 }}$ along with mRNA encoding a fluorescent marker as a lineage tracer (Fig. 3A). In this way, if PR-Set $7^{\mathrm{PIPM} 1 \mathrm{M} 2}$ is able to rescue the lethality caused upon loss of PR-Set7, the injected cell of the two-cell stage embryo of PR-Set7 ${ }^{-/-}$ embryos is expected to develop as normal and generate a blastocyst, while the other cell would serve as an internal control (Fig. 3A; Oda et al. 2009). Also, these experiments should reveal whether wild-type and heterozygous embryos would tolerate PR-Set $7^{\text {PIPM1M2 }}$ expression (Fig. 3A). Surprisingly, expression of PR-Set $7^{\text {PIPM1M2 }}$ was able to completely rescue the $P R-S e t 7^{-1-}$ embryos (Fig. 3B). Moreover, PR-Set $7^{\text {PIPM1M2 }}$ was tolerated in wild-type and heterozygous embryos (Fig. 3B). Importantly, expression of PR-Set $7^{\text {PIPM1M2 }}$ in embryonic nuclei did not lead to increased accumulation of $\gamma \mathrm{H} 2 \mathrm{~A} . \mathrm{X}$ (Fig. 3D). These results are in stark contrast to the phenotype observed upon expression of PR-Set $7^{\text {PIPM1M2 }}$ in differentiated cells, which led to the accumulation of DNA damage as well as multiple cell cycle defects, including G2/Mphase arrest and rereplication (Abbas et al. 2010; Tardat et al. 2010). Thus, the early embryo appears to contain control mechanisms for cell cycle progression and checkpoint control that are distinct from those within differentiated cell lines.

A particular feature of early embryonic chromatin is the absence of most typical heterochromatic marks, including H4K20me3 (Kourmouli et al. 2004; Burton and Torres-Padilla 2010). Given our results above, the lack of Suv4-20h activity in the early embryo may explain why PR-Set $7^{\text {PIPM1M2 }}$ does not result in growth arrest and elevated DNA damage. Thus, we next investigated whether coexpression of Suv4-20h1 in the embryo would lead to the toxicity associated with PR-Set $7^{\text {PIPM1M2 }}$ in differentiated cells. Indeed, in contrast to injection of the PR-Set $7^{\text {PIPM1M2 }}$ transcript alone, coinjection with the Suv4-20h1 transcript failed to rescue the PR-Set7-null embryos. Instead, expression of PR-Set $7^{\text {PIPM1M2 }}$ and Suv4-20h1 caused growth arrest and high levels of $\gamma \mathrm{H} 2 \mathrm{~A}$.X (Fig. 3C). This toxicity occurred independently of the PR-Set7 embryo genotype. These findings show that the toxic effects caused by stabilization of PR-Set7 during $S$ phase are mediated through Suv4-20 and, likely, H4K20me2/3.

Contrary to ES cells and transformed cells, loss of PRSet7 in the early embryo does not trigger DNA damage (Jorgensen et al. 2007; Oda et al. 2009). The results above suggest that the difference between PR-Set7 phenotypes in the early embryo, compared with ES cells and transformed cell lines, is dependent on Suv4-20. In support of this hypothesis, $P R-S e t 7^{-1-}$ embryos show massive DNA damage only when injected with Suv4-20h1 mRNA, as demonstrated by $\gamma \mathrm{H} 2 \mathrm{~A}$.X accumulation (Fig. 3E). Importantly, expression of Suv4-20h1 in wild-type or heterozygous embryos did not elicit DNA damage (Fig. 3E). Altogether, the lack of Suv4-20h activity in the normal embryo revealed two insights into PR-Set 7 biology during $S$ phase: The PR-Set $7^{\mathrm{PIPM} 2}$-mediated toxicity and the DNA damage incurred upon loss of PR-Set 7 are both dependent on Suv4-20h and H4K20me2/3. These results confirm that PR-Set7 has essential functions in the embryo unrelated to Suv4-20h, but that those related to $S$ phase in differentiated cells can be recapitulated in embryos forced to express Suv4-20h.

\section{$P R$-Set7 recruits the ORC through direct binding of ORC1 and ORCA to H4K2Ome2/3}

Given our findings that PR-Set7 misregulation leads to disruption in the cell cycle and abnormal DNA replication through Suv4-20h and H4K20me2/3, we next explored the mechanistic basis for the link between H4K20me2/3 and appropriate DNA replication. Our previous work, along with that of others, has shown that the ORC binds to H4K20me2/3 in vitro (Oda et al. 2010; Vermeulen et al. 
A

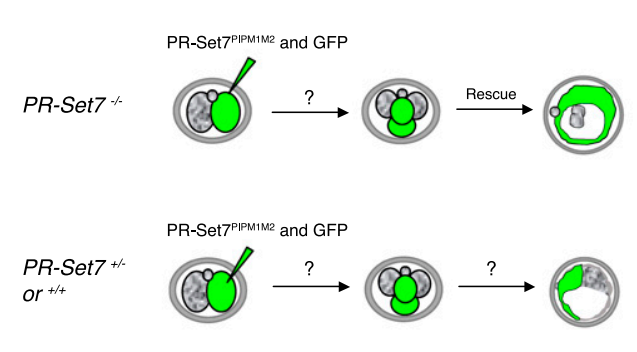

C

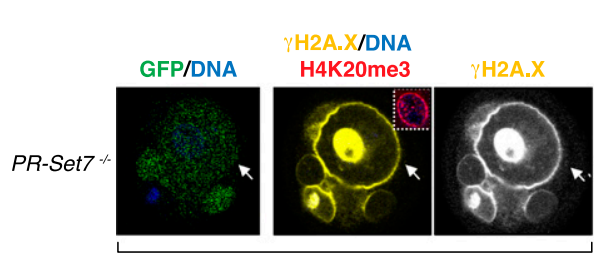

PR-Set7PIPM1M2 + Suv4-20h1 Injection
B

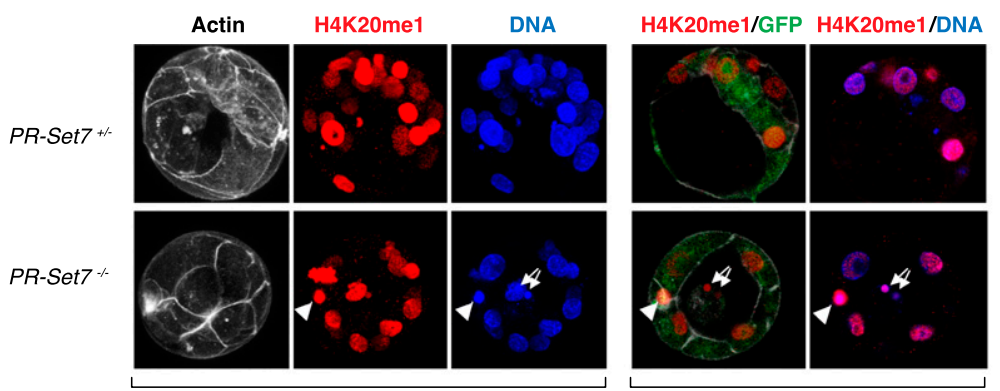

Full Z-Series Projections
Single/Merge Sections

PR-Set7 $7^{\text {PIPM1M2 Injection }}$

D

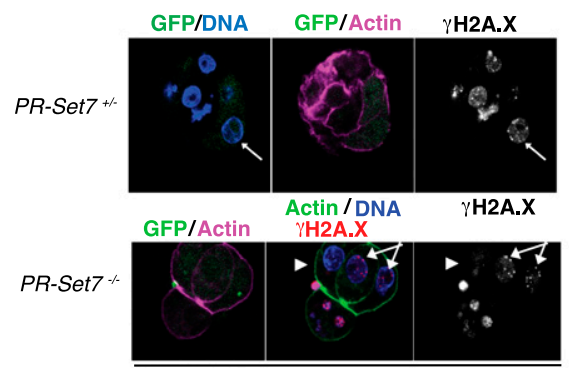

PR-Set7PIPM1M2 Injection
E

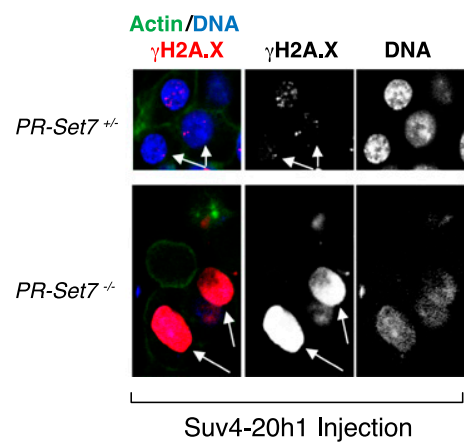

Figure 3. Both PR-Set $7^{\mathrm{PIPM} 2}$ and $P R-S e t 7^{-1-}$ phenotypes are dependent on Suv4-20 in the early embryo. $(A)$ Two-cell stage embryo injection experiment schematic depicting the possible outcomes for wild-type and heterozygous $P R$-Set7 embryos versus the null embryos. (B) PR-Set $7^{+/-}$and PR-Set $7^{-/-}$two-cell stage embryos were injected with PR-Set $7^{\text {PIPMIM2 }}$ mRNA. Injected cells are marked with GFP; the polar body is labeled by arrowheads, and $\mathrm{GFP}^{+}$cells are indicated by arrows. Embryos were monitored for growth and stained with H4K20me1 (red). Full Z-series projections and single sections are depicted. $(C) P R-\operatorname{Set} 7^{-/+}$and $P R-S e t 7^{-/-}$were injected with mRNA for PR-Set $7^{\text {PIPM1M2 }}$ in combination with Suv4-20h1 mRNA and GFP as a tracer. The arrows point to one of the injected cells. Embryos were stained with H4K20me3 (red) and $\gamma \mathrm{H} 2 \mathrm{~A} . \mathrm{X}$ (yellow). Insets show an injected cell stained for H4K20me3 (red) and DAPI (blue). (D) PR-Set $7^{-/+}$and PR-Set $7^{-/-}$were injected with PR-Set $7^{\text {PIPM1M2 }}$. Arrows point to injected cells, which were identified by the presence of GFP; the polar body is marked by arrowheads. Embryos were stained with $\gamma \mathrm{H} 2 \mathrm{~A}$.X, cortical actin, and DAPI (blue). (E) PR-Set $7^{-/-}$and PR-Set $7^{-/+}$embryos were injected with Suv4-20h1 mRNA alone and stained for cortical actin (green) and $\gamma \mathrm{H} 2 \mathrm{~A} . \mathrm{X}$ (red) accumulation. Injected cells (marked by arrows) were identified by the presence of GFP (not shown). The genotypes of individual embryos were determined after confocal acquisition as described previously.

2010). We hypothesized that H4K20me2/3 may serve as a recruitment mechanism for specific components of the ORC. To test this hypothesis, we first examined whether artificial recruitment of GAL4-PR-Set7 to a UAS site would lead to ORC recruitment. Using a 293T-REx cell line containing a stably integrated 5xUAS site directing luciferase expression, we expressed GAL-4 PR-Set7 under an inducible doxycycline-responsive promoter (Fig. 4A; Li et al. 2010). Chromatin immunoprecipitation (ChIP) analysis was performed at the UAS site as a function of GAL4PR-Set7 expression. PR-Set7 recruitment to the artificial UAS locus led to an approximately fourfold increase in ORCA and an approximately fivefold increase in ORC1 recruitment relative to untreated cells (Fig. 4B). Coincident with this recruitment was a statistically significant accumulation of H4K20me3 at the UAS site, which was generated from an earlier accumulation of H4K20me1 (Fig. 4B). Upon siRNA treatment for Suv4-20h1, H4K20me3 decreased at the UAS site with a concomitant reduction in ORC-1 and ORCA recruitment (Fig. 4B; Supplemental
Fig. 3). These data confirm that PR-Set7 participates in ORC recruitment at specific loci, without the requirement for any upstream factors, through Suv4-20 and H4K20me3 (Tardat et al. 2010).

After determining that ORC can be directly recruited to chromatin by PR-Set7, we next tested whether any ORC components can directly bind H4K20me2/3. After analyzing predicted chromatin-binding domains (http:// www.uniprot.org), we found that only two members of ORC could potentially accomplish this function: ORC1 with its BAH domain and ORCA with its WD40 domain. Recently, the ORC1 BAH domain was shown to specifically bind H4K20me2, further supporting this connection (Kuo et al. 2012). We used the BAH domain of ORC1 (amino acids 1-185) and full length ORCA in peptidebinding studies. The ORC-1 BAH domain bound primarily H4K20me2 in vitro (Fig. 4C). In contrast, ORCA showed a preference for H4K20me3. Thus, in combination with our previous unbiased peptide-binding experiments (Oda et al. 2010), these findings demonstrate that both ORC1 

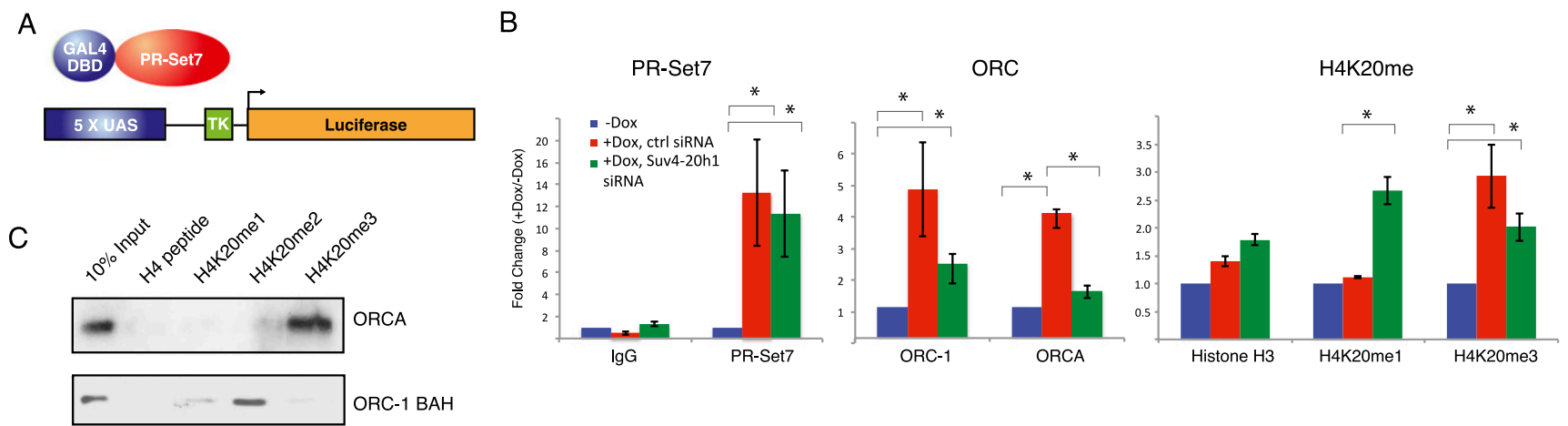

Figure 4. PR-Set7 recruits the ORC to chromatin through H4K20me. (A) Diagram depicting the GAL4-UAS system in 293T-REx cells. (B) ChIP analysis at an integrated UAS-binding site in 293T-REx cells before and after inducible expression of GAL4-PR-Set7 using GAL4, PR-Set7, H3, H4K20me1, H4K20me3, ORC1, and ORCA antibodies. (C) Peptide pull-down for the GST-ORC1 BAH domain and His-ORCA binding to unmethylated, H4K20me1, H4K20me2, and H4K20me3 peptides. $\left(^{\star}\right)$ Statistical significance with $P<0.05$.

and ORCA are involved in recruitment of the ORC to H4K20me2/3 sites. Together, our results show a direct mechanistic connection between PR-Set7 and the proper recruitment of the ORC through the products of Suv4-20 activity to effectively promote DNA replication.

\section{Discussion}

In this study, we showed that the oscillation in PR-Set7 protein levels during the cell cycle has direct repercussions on the proper recruitment of the ORC through H4K20me2/3 and Suv4-20h (Fig. 5). The disruption in PRSet7 oscillation and the associated catalysis of H4K20me1 lead to faulty DNA replication. Since the initial identification of PR-Set7 and Suv4-20, H4K20me has been functionally linked to proper cell cycle progression, specifically during mitosis and DNA replication (Fig. 5). This study places PR-Set7 and Suv4-20h as key chromatin mediators of DNA replication and specifies how their activities function in conjunction to ensure bona fide ORC recruitment to chromatin in higher eukaryotic cells.

We found that aberrant PR-Set7 stabilization during S phase causes robust rereplication. Rereplication was previously shown to be caused by the loss of the ubiquitin ligase Cdt2 (Arias and Walter 2007), and this abnormality can be completely suppressed by codepletion of PR-Set7. These results place PR-Set7 as a major effector of Cdt2 function. We also found that cell cycle defects in MEFs that express PR-Set $7^{\mathrm{PIPM} 2}$ are dependent on Suv4-20h and H4K20me2/3. Surprisingly, expression of PR-Set $7^{\text {PIPM1M2 }}$ is not toxic during early embryogenesis and can even rescue $P R-S e t 7^{-1-}$ embryos to an extent similar to wildtype PR-Set7. This is due to the minimal amount of H4K20me2/3 inherent to early embryogenesis. Consistent with this interpretation, coexpression of PR-Set $7^{\text {PIPM1M2 }}$ along with Suv4-20h1, as opposed to expression of either gene alone, caused growth arrest in the embryo. Together, these results connect PR-Set7 and Suv4-20h with regulation of replication during $S$ phase and DNA damage and accentuate that different regulatory processes guide the cell cycle between the early embryo and differentiated cells. Finally, we determined how H4K20me affects origin licensing by demonstrating that PR-Set7 can trigger recruitment of the ORC to chromatin and that ORC1 and ORCA bind H4K20me directly.

The sequence and determinants of origins of DNA replication in higher eukaryotes have remained elusive despite extensive investigation (Gilbert 2010). The metazoan ORC does not contain any intrinsic DNA-binding specificity and thus must require additional factors to be properly recruited. A leading hypothesis in the field has been that chromatin may be involved in this process. Our study provides mechanistic insights into how H4K20me may function during this critical process. Taken together, the regulation and timing of $\mathrm{H} 4 \mathrm{~K} 20 \mathrm{me} 1 / 2 / 3$ is critical for proper origin of replication firing.
A

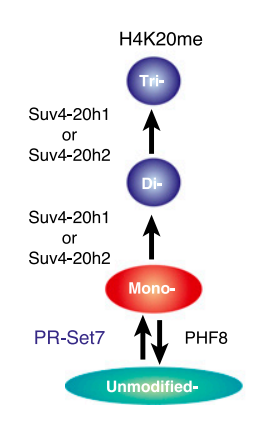

B

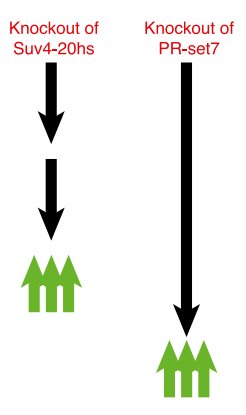

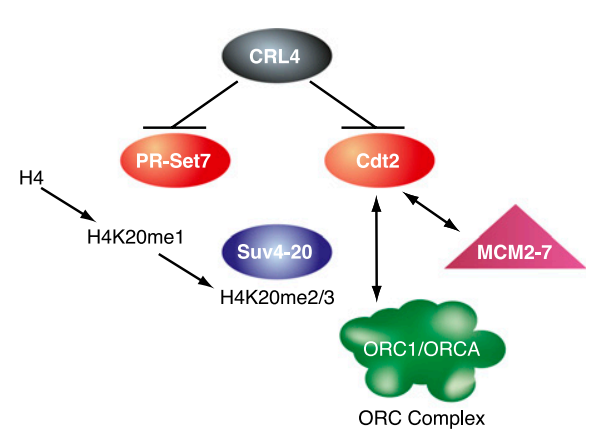

Figure 5. Summary of function of PR-Set7 and Suv4-20 $(A)$ along with their role in regulation of origin of replication licensing through CRL4 ${ }^{\mathrm{Cdt} 2}(B)$. 
In vivo, H4K20 is primarily found in both the monoand dimethylation state, raising the question of how these highly ubiquitous modifications affect the selection of DNA replication origins. Our findings, along with the previously demonstrated importance of regulation and timing of H4K20 methylation, suggest that H4K20me3, rather than H4K20me2, acts as a more specific guide for origin of replication selection, although both marks may contribute to this process. This situates H4K20me and the degree of such methylation as key components in an oscillating control mechanism for proper cell cycle progression, controlled in part by the degradation of PR-Set7. In addition, differential regulation of these modifications between the early embryo and later lineage-committed cells demonstrates the contrasting requirements for cell cycle progression during development.

\section{Materials and methods}

\section{Microinjection and embryo analysis}

Two-cell stage mouse embryos were isolated from $\mathrm{PR}-\mathrm{Set} 7^{-/+}$ crosses at $46 \mathrm{~h}$ post-hCG hormonal stimulation. Embryos were microinjected with 1-2 pL of mRNA transcribed in vitro from the pRN3P expression vector that contains $5^{\prime}$ and $3^{\prime}$ untranslated regions (UTRs) of the $\beta$-globin as described previously (Oda et al. 2009). Embryos were cultured in KSOM droplets under mineral oil under a $5 \% \mathrm{CO}_{2}$ atmosphere at $37^{\circ} \mathrm{C}$ and monitored for developmental progression daily. For immunostaining, embryos were fixed as described earlier (permeabilization with $0.5 \%$ Triton and washed three times in PBS-T $[0.1 \%$ Tween in PBS]), blocked, and incubated with the primary antibodies in $3 \%$ BSA and $0.1 \%$ Tween in PBS for $\sim 12 \mathrm{~h}$ at $4{ }^{\circ} \mathrm{C}$. Embryos were then washed twice in PBS-T, blocked for $30 \mathrm{~min}$, and incubated with the corresponding secondary antibodies and 4'-6-diamidino2-phenylindole. Embryos were then analyzed in individual drops using a TCS SP5 confocal microscope (Leica) and genotyped after acquisition.

\section{Cell culture and flow cytometry}

Suv4-20-/- and wild-type MEFs were kindly provided by Drs. Gunnar Schotta and Thomas Jenuwein. 293T-REx cells were purchased from Invitrogen, and HeLa and U2OS were acquired from the American Type Culture Collection (ATCC). Cells were grown using DMEM, 10\% FBS, $1 \%$ penicillin, $1 \%$ streptomycin, and $1 \%$ nonessential amino acids. For proliferation assays, cells were counted using a hemacytometer or cyto60 dye (Invitrogen). For flow cytometry, cells were trypsinized, washed once in cold PBS, and fixed in $70 \%$ ethanol for $20 \mathrm{~min}$ on ice. For cell cycle analyses, cells were washed and resuspended in PBS containing RNase A $(100 \mu \mathrm{g} / \mathrm{mL})$ and propidium iodide $(40 \mu \mathrm{g} / \mathrm{mL})$. EdU labeling was performed using the Click-iT EDU Alexa Fluor 488 flow cytometry assay kit (Invitrogen). Samples were run on a FACScalibur (Becton Dickinson), and data analysis was performed using FloJo (Dean-Jett-Fox cell cycle analysis platform) and ModFit LT 3.2.1.

\section{Protein extracts and microscopy}

Cells were lysed with buffer A (10 mM HEPES at pH 7.9, 0.1\% NP-40, $10 \mathrm{mM} \mathrm{MgCl}$, $250 \mathrm{mM}$ sucrose) containing protease inhibitors (Roche) and centrifuged. Nuclear pellets were lysed with buffer B (25 mM HEPES at pH 7.9, 20\% glycerol, $0.7 \mathrm{M}$
$\mathrm{NaCl}, 1.5 \mathrm{mM} \mathrm{MgCl}_{2}, 0.1 \mathrm{mM}$ EDTA), sonicated, and centrifuged. Proteins were separated on sodium dodecyl sulfatepolyacrylamide gels. For microscopy, cells were grown on coverslips, fixed with $4 \%$ paraformaldehyde, and stained using DAPI dye.

Gene silencing by siRNA and quantitative PCR (qPCR)-based detection

siRNA transfections were performed using RNAiMAX (Invitrogen) according to the manufacturer's specifications. The nucleotide sequences of siRNA and the primers used for detection are listed below. siRNAs for Hs PR-Set7 and si-AllStars as a negative control were purchased from Qiagen. siRNAs for Hs Cdt2 and Hs DDB1 were obtained from Invitrogen. siRNAs for Hs Cdt1, Hs Suv4-20h1, and Mm Cdt2 were ordered from Dharmacon.

siRNA oligos used were as follows: Hs PR-Set7-7 (target sequence: CTGCAGTCTGAAgAAAGGAAA), Hs PR-Set7-8 (sense, CCUGUUGAUUGCCAAAAACTTdTdT; antisense, GUU UUUGGCAAUCAACAGGdTdT), Hs Cdt2-1 (sense, GAAUUAU ACUGCUUAUCGAdTdT; antisense, UCGAUAAGCAGUAUAA UUCdTdT), Hs DDB1-1 (sense, ACAGAGUGGCGAGAGCAUU dTdT; antisense, AAUGCUCUCGCCACUCUGUdTdT), Hs DD B1-2 (sense, CCUGUUGAUUGCCAAAAACTTdTdT; antisense, GUUUUUGGCAAUCAACAGGdTdT), Hs Cdt-1 (Dharmacon si genome pool), and Mm Cdt-2 (Dharmacon si genome pool).

Detection primers used were as follows: Hs Cdt1 1508 S (GCTGTTGTACTATCATGAGCCC), Hs Cdt1 1626 AS (GTCC AGCTTGACGTAGGTGTC), Hs Cdt2 308 S (GACCCTGATGC TCTTCAATTC), Hs Cdt2 402 AS (ACCACTGCACTGATAAC CAGTC), Mm Cdt2 24 S (ACGATGAACACACGTCTTATGG), Mm Cdt2 357 AS (AGCCTTCTTCATTAGCAACTGC), Mm mGapdh S (CAAGCTCATTTCCTGGTATGAC), Mm Gapdh AS (CTCCTGTTATTATGGGGGTCTG), Hs Gapdh S (AACCA TGAGAAGTATGACAACAGC), and Hs Gapdh AS (CAGTCT TCTGGGTGGCAGTG).

Plasmids

Human PR-Set7 wild-type and mutants were subcloned into the pMSCV Puro retroviral vector (Invitrogen). pINTO GAL4 PR-Set7 and 3xFlag-tagged PR-Set7 were cloned as an Xhol/BamHI fragment into the pMSCV TtIGPP vector (S. Lowe Laboratory, Cold Spring Harbor Laboratory [CSHL]). iTetONGR * (Anastassiadis et al. 2002) was cloned as an EcoRI/BamHI fragment into pMSCV MB (M. Huebner, CSHL). Additional Suv4-20h1 and PR-Set $7^{\text {PIPM1M2 }}$ were cloned into the pRNP3 vector. ORC-1 and ORCA domains were cloned from HeLa cDNA into pGEX6P1 (GE Life Sciences) and pET30a (Novagen), respectively, using BamHI and NotI restriction enzymes. Retrovirus was produced in $293 \mathrm{~T}$ cells according to standard methods and then used to infect MEFs.

\section{Antibodies and reagents}

The sources for the following reagents were as follows: PR-Set7 (custom), H3 (Abcam), H4K20me1 (Abcam), H4K20me3 (Abcam), $\gamma$ H2A.X (Millipore), DDB1 antibody (Invitrogen), $\beta$-tubulin (Abcam), PCNA (Santa Cruz Biotechnology), actin (Abcam), ORC1 (Abcam), ORCA (Bethyl), and GAL4 (Millipore).

\section{ChIP}

ChIP was performed using 293T-REx inducible cell lines with a stably inserted 6xUAS-TK-LUC. ChIP was performed $48 \mathrm{~h}$ after induction of GAL4-PR-Set7 expression using $1 \mu \mathrm{g} / \mathrm{mL}$ doxycycline. Detection was performed using primers against the TK Luc promoter (5'-CACCGAGCGACCCTGCATAAG-3' and 5'-GCT 
Beck et al.

TCTGCCAACCGAACGGAC-3'). ChIP protocol was performed as described previously (Gao et al. 2012).

\section{Peptides and recombinant pull-downs}

GST-ORC1 BAH domain (amino acids 1-185) and His-ORCA (full length) were incubated with biotinylated $\mathrm{H} 4$ peptides (amino acids 9-28) with specified post-translational modifications. One microgram of the above recombinant protein was incubated with $1 \mu \mathrm{g}$ of peptide (preincubated with Streptactin macroprep beads [IBA]) for $4 \mathrm{~h}$ to overnight and then washed with $10 \mathrm{mM}$ Tris $(\mathrm{pH} 7.9), 500 \mathrm{mM} \mathrm{KCl}, 0.2 \mathrm{mM}$ EDTA, and $5 \%$ Sarkosyl detergent prior to binding analysis by Western blotting.

\section{Acknowledgments}

We are grateful to Stephanie Kim, Deborah Hernandez, and Brent Kopenhaver for technical assistance, and members of the Reinberg laboratory for helpful discussions. We also thank Drs. Gunnar Schotta and Thomas Jenuwein for Suv4-20 dn MEFs, Gary Felsenfeld for insulator DNA sequences, Pascal Eberling for preparing H4K20me peptides, Michael Huebner and David Spector for retroviral inducible system, Zhiguo Zhang for the ORCA baculovirus, and Lynne Vales for comments on the manuscript. This work was supported by grants from the NIH (GM64844 to D.R.) and HHMI (to D.R.). Research in the TorresPadilla laboratory was supported by ANR-09-Blanc-0114, FP7 EpiGeneSys NoE, and an ERC-Stg Grant ("NuclearPotency"). A.B. is supported by a post-doctoral fellowship from the Fondation pour la Recherche Medicale.

\section{References}

Abbas T, Dutta A. 2011. CRL4Cdt2: Master coordinator of cell cycle progression and genome stability. Cell Cycle 10: 241-249.

Abbas T, Shibata E, Park J, Jha S, Karnani N, Dutta A. 2010. CRL4(Cdt2) regulates cell proliferation and histone gene expression by targeting PR-Set7/Set8 for degradation. Mol Cell 40: 9-21.

Anastassiadis K, Kim J, Daigle N, Sprengel R, Scholer HR, Stewart AF. 2002. A predictable ligand regulated expression strategy for stably integrated transgenes in mammalian cells in culture. Gene 298: 159-172.

Arias EE, Walter JC. 2007. Strength in numbers: Preventing rereplication via multiple mechanisms in eukaryotic cells. Genes Dev 21: 497-518.

Beck DB, Oda H, Shen SS, Reinberg D. 2012. PR-Set7 and H4K20me1: At the crossroads of genome integrity, cell cycle, chromosome condensation, and transcription. Genes Dev 26: 325-337.

Burton A, Torres-Padilla ME. 2010. Epigenetic reprogramming and development: A unique heterochromatin organization in the preimplantation mouse embryo. Brief Funct Genomics 9: 444-454.

Centore RC, Havens CG, Manning AL, Li JM, Flynn RL, Tse A, Jin J, Dyson NJ, Walter JC, Zou L. 2010. CRL4(Cdt2)-mediated destruction of the histone methyltransferase Set8 prevents premature chromatin compaction in S phase. Mol Cell 40: 22-33.

Eaton ML, Prinz JA, MacAlpine HK, Tretyakov G, Kharchenko PV, MacAlpine DM. 2011. Chromatin signatures of the Drosophila replication program. Genome Res 21: 164-174.

Gao Z, Zhang I, Bonasio R, Strino F, Sawai A, Parisi F, Kluger Y, Reinberg D. 2012. PCGF homologs, CBX proteins, and RYBP define functionally distinct PRC1 family complexes. Mol Cell 45: 344-356.
Gilbert DM. 2010. Evaluating genome-scale approaches to eukaryotic DNA replication. Nat Rev Genet 11: 673-684.

Havens CG, Walter JC. 2011. Mechanism of CRL4(Cdt2), a PCNA-dependent E3 ubiquitin ligase. Genes Dev 25: 15681582.

Houston SI, McManus KJ, Adams MM, Sims JK, Carpenter PB, Hendzel MJ, Rice JC. 2008. Catalytic function of the PR-Set7 histone $\mathrm{H} 4$ lysine 20 monomethyltransferase is essential for mitotic entry and genomic stability. J Biol Chem 283: 1947819488.

Jorgensen S, Elvers I, Trelle MB, Menzel T, Eskildsen M, Jensen ON, Helleday T, Helin K, Sorensen CS. 2007. The histone methyltransferase SET8 is required for S-phase progression. J Cell Biol 179: 1337-1345.

Karnani N, Taylor CM, Malhotra A, Dutta A. 2010. Genomic study of replication initiation in human chromosomes reveals the influence of transcription regulation and chromatin structure on origin selection. Mol Biol Cell 21: 393-404.

Kourmouli N, Jeppesen P, Mahadevhaiah S, Burgoyne P, Wu R, Gilbert DM, Bongiorni S, Prantera G, Fanti L, Pimpinelli S, et al. 2004. Heterochromatin and tri-methylated lysine 20 of histone H4 in animals. J Cell Sci 117: 2491-2501.

Kuo AJ, Song J, Cheung P, Ishibe-Murakami S, Yamazoe S, Chen JK, Patel DJ, Gozani O. 2012. The BAH domain of ORC1 links H4K20me2 to DNA replication licensing and Meier-Gorlin syndrome. Nature 484: 115-119.

Li G, Margueron R, Ku M, Chambon P, Bernstein BE, Reinberg D. 2010. Jarid2 and PRC2, partners in regulating gene expression. Genes Dev 24: 368-380.

Liu W, Tanasa B, Tyurina OV, Zhou TY, Gassmann R, Liu WT, Ohgi KA, Benner C, Garcia-Bassets I, Aggarwal AK, et al. 2010. PHF8 mediates histone H4 lysine 20 demethylation events involved in cell cycle progression. Nature 466: 508-512.

Mesner LD, Valsakumar V, Karnani N, Dutta A, Hamlin JL, Bekiranov S. 2011. Bubble-chip analysis of human origin distributions demonstrates on a genomic scale significant clustering into zones and significant association with transcription. Genome Res 21: 377-389.

Nishioka K, Rice JC, Sarma K, Erdjument-Bromage H, Werner J, Wang Y, Chuikov S, Valenzuela P, Tempst P, Steward R, et al. 2002. PR-Set7 is a nucleosome-specific methyltransferase that modifies lysine 20 of histone $\mathrm{H} 4$ and is associated with silent chromatin. Mol Cell 9: 1201-1213.

Oda H, Okamoto I, Murphy N, Chu J, Price SM, Shen MM, Torres-Padilla ME, Heard E, Reinberg D. 2009. Monomethylation of histone H4-lysine 20 is involved in chromosome structure and stability and is essential for mouse development. Mol Cell Biol 29: 2278-2295.

Oda H, Hubner MR, Beck DB, Vermeulen M, Hurwitz J, Spector DL, Reinberg D. 2010. Regulation of the histone H4 monomethylase PR-Set7 by CRL4(Cdt2)-mediated PCNA-dependent degradation during DNA damage. Mol Cell 40: 364-376.

Qi HH, Sarkissian M, Hu GQ, Wang Z, Bhattacharjee A, Gordon DB, Gonzales M, Lan F, Ongusaha PP, Huarte M, et al. 2010. Histone H4K20/H3K9 demethylase PHF8 regulates zebrafish brain and craniofacial development. Nature 466: 503-507.

Rice JC, Nishioka K, Sarma K, Steward R, Reinberg D, Allis CD. 2002. Mitotic-specific methylation of histone H4 Lys 20 follows increased PR-Set7 expression and its localization to mitotic chromosomes. Genes Dev 16: 2225-2230.

Schotta G, Sengupta R, Kubicek S, Malin S, Kauer M, Callen E, Celeste A, Pagani M, Opravil S, De La Rosa-Velazquez IA, et al. 2008. A chromatin-wide transition to H4K20 monomethylation impairs genome integrity and programmed DNA rearrangements in the mouse. Genes Dev 22: 20482061. 
Tardat M, Murr R, Herceg Z, Sardet C, Julien E. 2007. PR-Set7dependent lysine methylation ensures genome replication and stability through S phase. I Cell Biol 179: 1413-1426.

Tardat M, Brustel J, Kirsh O, Lefevbre C, Callanan M, Sardet C, Julien E. 2010. The histone H4 Lys 20 methyltransferase PRSet7 regulates replication origins in mammalian cells. Nat Cell Biol 12: 1086-1093.

Vermeulen M, Eberl HC, Matarese F, Marks H, Denissov S, Butter F, Lee KK, Olsen JV, Hyman AA, Stunnenberg HG, et al. 2010. Quantitative interaction proteomics and genomewide profiling of epigenetic histone marks and their readers. Cell 142: 967-980.

Zee BM, Britton LM, Wolle D, Haberman DM, Garcia BA. 2012. Origins and formation of histone methylation across the human cell cycle. Mol Cell Biol 32: 2503-2514. 


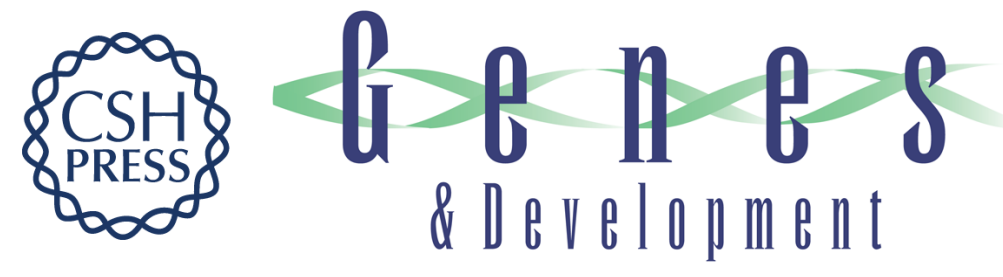

\section{The role of PR-Set7 in replication licensing depends on Suv4-20h}

David B. Beck, Adam Burton, Hisanobu Oda, et al.

Genes Dev. 2012, 26: originally published online November 14, 2012

Access the most recent version at doi:10.1101/gad.195636.112

Supplemental

Material

References

License

Email Alerting Service
This article cites 29 articles, 15 of which can be accessed free at:

http://genesdev.cshlp.org/content/26/23/2580.full.html\#ref-list-1

http://genesdev.cshlp.org/content/suppl/2012/11/12/gad.195636.112.DC1

Receive free email alerts when new articles cite this article - sign up in the box at the top right corner of the article or click here.

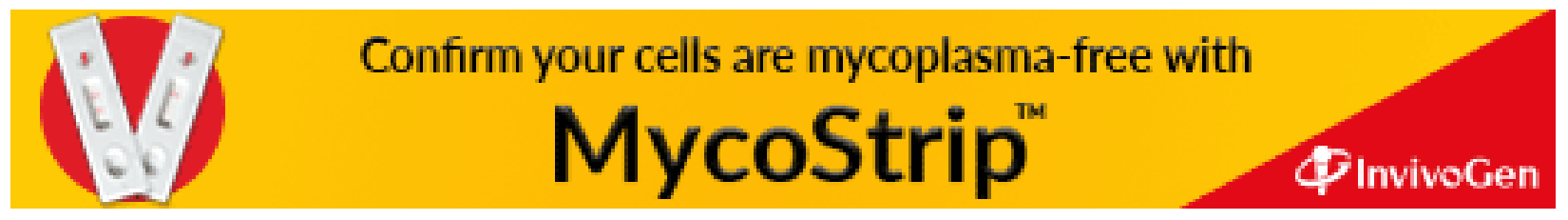

